\title{
Islamic Banking Sustainability: Theory and Evidence Using a Novel Quadruple Bottom Line Framework
}

\author{
M. LUTHFI HAMIDI, $I^{t, H} D$ ANDREW C. WORTHINGTON \\ ${ }^{+}$Sekolah Tinggi Ekonomi Islam (SEBI), \\ Jawa Barat, Indonesia \\ mluthfi.hamidi@griffithuni.edu.au \\ * Department of Accounting, Finance and Economics \\ Griffith University \\ Nathan, QLD 4111, Australia \\ a.worthington@griffith.edu.au \\ * Corresponding author
}

\begin{abstract}
Purpose - To extend the conventional triple bottom line (TBL) framework (prosperity, people, planet) to the quadruple bottom line (QBL) by newly adding a 'prophet' dimension for Islamic banks seeking compliance with Islamic law in their pursuit of sustainability.

Design/methodology/approach — Employ Chapra's corollaries of maqasid al-shari'ah (the goals of Islamic law) to develop constructs for a survey of 504 Islamic bank stakeholders from five Indonesian provinces to gather primary data to quantitatively verify the dimensions and items in the proposed QBL framework. Categorical principal component analysis (CATPCA) then identifies the sustainability of ten Islamic banks from ten countries as a trial application of the resulting QBL index.
\end{abstract}

Findings - Using the dimensions and items identified using CATPCA, we develop a QBL index to assess the sustainability of the ten Islamic banks. The findings suggest that half of the banks are sufficiently sustainable, with three being proactive (doing more than is required) and two being accommodative (doing all that is required). The remaining five banks are unsustainable, with two banks being defensive (doing the least that is required) and three being reactive (doing less than is required). Most of the banks perform relatively poorly according to the 'planet' (38\%) and 'people' (41\%) dimensions and perform better on the 'prosperity' $(53 \%)$ and 'prophet' $(63 \%)$ dimensions. Nonetheless, there is ample room for improvement across all dimensions of sustainability.

Originality - Pioneering exploration of TBL from maqasid al-shari'ah perspective. First, we develop a QBL index to assess the sustainability of Islamic banks in line with actual stakeholder expectations.

Research limitations/implications - The generalizability of the findings is limited by the small-scale single-country survey used in the CATPCA part of the analysis. Only ten Islamic banks were included in the QBL scoring and ranking exercises. 
Practical implications — Islamic banks can improve their sustainability by increasing green financing and reaching out to rural areas and disadvantaged populations. In countries with Islamic banking systems, regulators can support this through training, guidance, and incentives.

Keywords - triple bottom line (TBL), quadruple bottom line (QBL), Islamic banking, maqasid al-shari'ah, categorical principal component analysis (CATPCA)

Paper type - Research paper 
The need for sustainability is now widely recognized among most businesses, notably among banks. Some scholars have attributed this growing need for sustainability to the environment and others to corporate social responsibility (CSR) (Bansal and DesJardine, 2014). Kotler (2011) warns against the massive degradation of the environment from excessive resource exploitation, climate change, and the freshwater crisis and the role banks potentially play in financing this damage. For its part, CSR has a profound impact on competitive advantage for both banks and their customers (Bakker et al., 2005; Vilanova et al., 2009). Managing environmental and social issues has thus become unavoidable. All businesses, including banks, need to adapt to meet changing customer needs by adopting strategies that are consistent with these changes (Peattie and Charter, 2003).

Elkington (1997) focused on the longstanding debate on sustainability and a workable framework on three dimensions: economic achievement (Prosperity), social justice (People), and environmental quality (Planet). These are now commonly known as the triple bottom line (TBL). While TBL is not without criticism (Dyllick and Hockerts, 2002; Hubbard, 2009; Slaper and Hall, 2011), it has gained popularity as a standard approach to assessing business performance (Norman and MacDonald, 2004; Colbert and Kurucz, 2007). Some scholars argue that TBL excludes innovation as an essential requirement for a successful business over time (Pinkse and Kolk, 2010; Gao and Bansal, 2013; Longoni and Cagliano, 2018). Others assert that the social and environmental dimensions of TBL by design attract less attention (Hart and Milstein, 2003; Norman and MacDonald, 2004; Tate and Bals, 2018).

It is also surprising that despite its widespread use, few Islamic banks have adopted TBL when evaluating their social and environmental outcomes. In its place, some have developed indexes based on maqasid al-shari'ah (the goals of Islamic law) to measure Islamic socio-developmental performance (Asutay and Harningtyas, 2015; Bedoui and Mansour, 2015; Mohammed et al., 2015; Hasan et al., 2018). Others employ CSR as a performance measurement tool (Dusuki and Abdullah, 2007; Mallin et al., 2014; Platonova et al., 2018). The primary motivation for this is that conventional TBL lacks religious dimensions. This is important because in Islamic banks, maqasid al-shari'ah is inseparable from performance measurement as Islamic banks should deliver this as confirmation of all banking activities meeting the necessary Islamic goals.

Fortunately, to some extent, the existing TBL principles (prosperity, people, and planet) align with the spirit of maqasid al-shariah. For instance, Islamic banks typically aim to promote prosperity for all, achieve a fair and balanced society (Naqvi, 2016), and endorse social goals (Usmani, 2002). Some Islamic bank products, such as qardh al-hasan (benevolent 
loans) and cash waqf (charitable donations), amply illustrate this point. Maqasid al-Shariah also involves campaigning for the protection and preservation of nature (Islam, 2004; Murad, 2012) as part of its environmental goals. However, existing TBL principles are limited in any explicit practical guidance that aligns with Islamic principles. For instance, Islamic banks must also not provide loans based on interest ( $r i b a$ ) nor involve themselves in any speculative transactions or projects (gharar) or gambling (maisir). Thus, there is a need to extend the TBL with values important to Islamic banks given that they are part of maqashid al-shariah goals and that ignoring them may cause some aspects of Islamic banking to be not fully implemented.

Accordingly, the purpose of this paper is to offer some insights into how TBL can apply to Islamic banks. We first developed a new TBL model compliant with the spirit of maqasid al-shari'ah, as verified by the surveyed perceptions of Islamic bank stakeholders. This contrasts with existing work in the area and the use of secondary data (Haniffa and Hudaib, 2007; Williams and Zinkin, 2010; Mallin et al., 2014; Platonova et al., 2018). We then employed categorical principal component analysis (CATPCA) to extract key items later used in an index to assess the financial (prosperity), social (people), environmental (planet), and spiritual (prophet) performance of selected global Islamic banks. We refer to this extended TBL as the quadruple bottom line (QBL) given the now 4Ps. Finally, we tested where a sample of Islamic banks fit on a reactive, defensive, accommodative, and proactive (RDAP) scale (Hamidi and Worthington, 2018) using this index. This helps inform Islamic banks about the dimensions that require improvement to enhance their sustainability.

The remainder of this paper is structured as follows. The first section presents the theoretical framework, including how TBL could potentially incorporate the additional Prophet dimension, yielding a QBL framework for Islamic banking. The second section develops the methodology of developing the QBL framework and the primary and secondary data used, and the third section discusses the empirical results. The final section highlights some limitations of this analysis and some practical recommendations for improving the sustainability of Islamic banking.

\section{Theory and existing application}

\section{Conventional TBL}

The idea of conducting business exclusively for profit has led to a long debate. Friedman (1970) argued that the main responsibility of business was to increase profits, while 
Frederick (1960) declared that private interests could actually be synchronized with those of society. Typically, the exclusive focus on profits by businesses creates tensions with stakeholders. However, businesses can also create externalities (at least some positive) that improve distributive justice (Kolb, 2011; Maltz et al., 2011). In respect of this, Elkington (1997) suggested that TBL believes that business operations should be economically sustainable while simultaneously preserving the environment and enhancing the socioeconomic well-being of the societies in which they operate. The TBL framework gained widespread acknowledgment and application in the assessment of corporate sustainability (Milne et al., 2008).

Unfortunately, there is no consensus on the precise definition of TBL. It can be described as economic, social, and environmental performance, as well as economic prosperity, social justice and environmental quality, profit, people, the planet, livelihoods, lifestyles, and landscapes. However, these various descriptions of TBL have very similar meanings. In this paper, we use the 3Ps (prosperity, people, and planet), arguing that 'prosperity' is more meaningful than profit in that it can promote economic benefits for the firm and enhance the socio-economic well-being of workers and communities (Hammer and Pivo, 2017).

Several studies have considered different approaches to maximize TBL for corporate valuation. Hubbard (2009) extended the TBL framework by using a balanced scorecard (BSC) and creating an index so that the performance of business organizations was more accessible to their stakeholders. In the construction industry, Kucukvar and Tatari (2013) quantified the industry's impact on the economy, society, and the environment by applying an input-outputbased TBL framework. In the retail industry, Wilson (2015) applied the TBL principle in Marks and Spencer's (M\&S) sustainability strategy. Elsewhere, Hollos et al. (2012) considered sustainability among business suppliers, while Assaf et al. (2012) and Dyllick and Hockerts (2002) considered the dimensions of eco-efficiency, socio-efficiency, eco-effectiveness, socioeffectiveness, sufficiency, and ecological equity in the hospitality industry.

The framework of TBL has also been applied in the banking sector, particularly in social banking, because it follows TBL principles in its day-to-day business (San-Jose et al., 2011; Cornée and Szafarz, 2014). Triodos Bank is a striking sample. In its annual reports, Triodos Bank provides not only financial highlights, but also those concerning social and environmental outcomes. These include, alongside conventional financial information, TBL and the real economy as balance sheets, social impacts on the number and turnover of coworkers, the share of women in management and salaries, and environmental effects, including the bank's own greenhouse gas emissions and those added or removed through its loans and 
investments (Triodos Bank, 2019). While conventional banks also provide some of this information, few go as far as social banks.

\section{Islamic banking TBL}

Bank Muamalat Malaysia Berhard (BMMB) is currently the only Islamic bank to join the Global Alliance of Banking on Values, an umbrella organization for social banks. In its most recent annual report, BMMB (2019) stated that its mission was to deliver value to stakeholders, society, and the environment in line with maqasid al-shari'ah goals. The report also declared that social features existed in all of its products, along with the creation of a waqf fund distributing assistance to almost 5,000 medical patients in need and 2.5 million Malaysian ringgits directed to funding environmental, health, cultural, and religious causes.

Much of this flows from the fact that there is a relevant wisdom behind every law stipulated in Islam. Fasting during Ramadhan, for instance, enhances one's connectedness with God. These wisdoms indicate the objectives of Islamic law, and maqasid al-shari'ah are the underlying objectives (Auda, 2008). In a broad sense, these all provide benefits, prevent disadvantage, and free someone from evil and the unjust (Al-Qahtani, 2015). Maqasid alshari'ah is also a basic element governing human life in that ignoring it may create chaos and uncertainty (Mohammad and Shahwan, 2013). Islamic banks are expected to internalize and achieve maqasid al-shari'ah in their day-to-day operations. Failure to do so will mean that the bank is unable to reflect fully genuine Islamic aspirations (Chapra, 2007a).

Early theories of maqasid al-shari'ah referred to a categorization of essentials, needs, and enhancements. Essentials are things that must be met otherwise human life will be in danger. For example, it considers banning Muslims from consuming intoxicants and alcohol as essential in protecting their minds and bodies. Needs refer to things less essential for human life, while enhancements help embellish these goals. Most famously, Abu Hamid Al-Ghazali (d. 1111) further divided the essentials into five categories: (1) preservation of faith (din), (2) protecting the soul (nafs), (3) protecting the mind ('aql), (4) protecting offspring (nasl), and (5) protecting wealth ( $\mathrm{mal}$ ) (Chapra, 2007b).

However, some contemporary scholars criticize these five categories. For instance, some argue that maqasid should extend from the individual to the community or even nation (ummah) (Auda, 2008). Another criticism is that maqasid is limited in terms of universal values, such as justice and human rights. In response, in 2006, Al-Najjar extended the so-called Ghazalian maqasid to human rights, minds, and social entities (as cited in Bedoui and Mansour, 
2015), while Chapra (2007b) proposed its extension to well-being, suggesting secondary goals (tabi'ah) as a complement to the primary pillars (al-ashliyyah).

Once applied in banking, maqasid al-shari'ah plays a significant role in ensuring the legality of Islamic transactions and promoting people's welfare (Ariff and Rosly, 2011). For instance, Dusuki and Abdullah (2007) observed maqasid al-shari'ah's encouragement to the stakeholders of Islamic banks to support the application of corporate social responsibility and how this helped banks to move toward enhancing social welfare rather than profit maximization. This contradicts the argument made by some scholars that Islamic banks are becoming more profit-oriented in competitive markets and rebalancing away from the social outcomes suggested by maqasid al-shari'ah has become less syari'ah-compliant (Nienhaus, 2011; Mohammad and Shahwan, 2013; Maali and Atmeh, 2015). As a result, the ethical aspect of Islamic banks might not operate fully (Mansour et al., 2015) and could jeopardize their fundamental role in maximizing benefits and preventing harm (Chapra, 2007b; Mansour et al., 2015).

As indicated earlier, TBL principles guide banks to flourish and spread their benefits to stakeholders, thereby making the world a better place, which makes TBL (prosperity, people, and planet) consistent with the objectives of Islamic teaching. Theoretically, Islamic banking includes both the 'prosperity' and 'people' dimensions. This is because the primary objective of Islamic banking is not solely to realize financial gains, but also promote social justice and well-being (Usmani, 2002; Haniffa and Hudaib, 2007). The connection with the environment is less obvious but the Qur'an (30:41) states that, "Mischief has appeared on land and sea because of (the meed) that the hands of men have earned, that (Allah) may give them a taste of some of their deeds: in order that they may turn back (from Evil)". We can use this to assert that Islam also envisages the preservation and protection of nature.

Regarding the proposed 'prophet' dimension, the Qur'an identifies the conventional 3Ps in one verse, but with an added spiritual element: searching for the happiness of hereafter (Qur'an 28:77), a task unattainable without the guidance of the prophet (Qur'an 3:31; 53:2-4).

But seek, with what Allah has given you, the Home of the Hereafter [PROPHET], and do not neglect your share of this world [PROSPERITY]. And be charitable, as Allah has been charitable to you [PEOPLE]. And do not seek corruption in the land. Allah does not like the seekers of corruption [PLANET] (Ali, 1991, p. 1143).

The original context of the verse is the story of Qarun (Korah in the Old Testament), a wealthy man at the time of the Prophet Moses, who rebelled and became arrogant and oppressed his people (Qur'an 28:76). The account ended when the earth swallowed both him 
and all his treasures (Qur'an 28:81). The moral guidance in this story is that when an individual (or organization like an Islamic bank) emphasizes only a single bottom line (financial success) and pays no attention to the other values (or dimensions), life will be unsustainable.

\section{$<$ INSERT FIGURE 1 HERE $>$}

In this paper, we argue that the three original elements of TBL (prosperity, people, and planet) can easily adapt to Islamic banking by including 'prophet' as an additional dimension. Previously, Hamidi and Worthington (2018) constructed a mathematical formula to measure performance in the 4Ps (prosperity, people, planet, and prophet) and simulated its application to banks. However, that simulation did not include actual data. Figure 1 presents the relations between these 4Ps in their proposed QBL, their corresponding elements in maqasid al-shari'ah and either Chapra's (2007b) corollaries or the dimension of 'planet' proposed by Allet (2012).

\section{Empirical method}

Data

The first set of data used in applying the QBL is from hard copy and internet surveys. As the survey was a self-administered questionnaire, there was no opportunity to explain or clarify questions from the respondents. To overcome this, we administered an online pilot test between November 21 and December 29, 2017 that 137 respondents completed. Based on feedback from this pilot test, a revised questionnaire was developed, and 420 questionnaires were distributed across five Indonesian provinces (DKI Jakarta, Banten, West Java, Central Java, and DI Yogyakarta), with 259 responses, augmented by an online survey between February 1 and March 1, 2018, with an additional 245 responses. We employed nonprobability convenience sampling, a technique widely used in banking research (Pikkarainen et al., 2006;

Poon, 2007; Kumar et al., 2009), with teams of undergraduate students physically or distributing online the questionnaires to stakeholders of Islamic banks.

The questionnaire consisted of responses to multiple-choice questions in the first part and responses to questions along a seven-point Likert scale in the second part. The first part consisted of questions concerning individual demographic and socioeconomic characteristics and followed existing research in the area (Mohd Nor et al., 2016). The second part surveyed stakeholders about their perceptions of maqasid al-shari'ah expected to form the new QBL framework. The table in the appendix details the items to which respondents responded and 
associated corollaries and dimensions. Respondents responded to these on an ordinal scale from strongly agree to strongly disagree. We used these surveyed expectations and perceptions of Islamic banking to inform us which parts of the 4Ps are important to stakeholders and use them to score the performance of actual banks.

Table 1 summarizes the profile of respondents. It shows that more males $(59.9 \%)$ than females $(40.1 \%)$ participated in the survey. Most of the respondents were aged 26-35 years (39.9\%), followed by those aged 36-45 years (25.2\%). In line with the Indonesian population as a whole, most of the respondents lived in West Java (34.3\%), followed by DKI Jakarta (19\%), DI Yogyakarta (17.1\%), Central Java (12.3\%), Outside Java (8.5\%), Banten (4.6\%), and East Java (4.2\%). In terms of education, 44 (8.7\%) held a college diploma, 297 (58.9\%) had a bachelor's degree, 96 (19\%) had a master's degree, and 16 (3.2\%) had a doctoral degree. Most respondents were employees (40.9\%), with the other main categories being managers/executives $(15.6 \%)$, professionals $(10.5 \%)$, academics $(8.3 \%)$, merchant/business owners (7.9\%), and government employees (7.5\%). The most common income ranges are IDR 2-5 million (41.1\%) and 5-10 million (21.8\%), which broadly correspond to middle to lower middle incomes in Indonesia. In relation to Islamic banking, most of the respondents $(72.2 \%)$ held accounts with an Islamic as well as a conventional bank, with most being either a depositor $(36.7 \%)$ or a depositor and practitioner $(31.7 \%)$.

\section{$<$ INSERT TABLE I HERE $>$}

The second set of data is for Islamic banks listed in Global Finance (2018). We selected the leading Islamic banks from each of the 10 countries and used content analysis to analyze their annual reports from 2015 to 2017 . With this information, we assessed and ranked their performance using our QBL index. We selected the following banks (abbreviation and country headquarters in brackets): Al-Rajhi Bank (ARB, Saudi Arabia), Al-Baraka Islamic Bahrain (AIB, Bahrain), Meezan Bank (MB, Pakistan), Boubyan Bank (BB, Kuwait), Bank Muamalat Indonesia (BMI, Indonesia), Jordan Islamic Bank (JIB, Jordan), Emirates Islamic Bank (EIB, UAE), Kuveyt Türk Katilim Bankasi (KTKB, Turkey), Qatar Islamic Bank (QIB, Qatar), and Bank Muamalat Malaysia Berhard (BMBM, Malaysia).

\section{Method}

We used categorical principal component analysis (CATPCA) to refine a large number of items concerning perceptions of Islamic banks in the appendix and acquired through the 
survey into a manageable number of uncorrelated principal components (Linting et al., 2007). The resulting components represent variables of interest, and the score index obtained from this method can be used as a measurement tool (Härdle and Hlávka, 2015; Howard et al., 2015). A number of other studies used this same method to condense variables into smaller, more manageable sets of data and develop composite indexes (Comim and Amaral, 2013; Saukani and Ismail, 2019).

We then used content analysis to analyze the annual report information, with the coding derived from the composite TBL index extracted using CATPCA and representing the 13 items distributed across the four dimensions. We developed all constructs from the theory of maqasid al-shari'ah in conjunction with the broader Islamic banking literature. The scoring of items follows the dichotomous approach (Haniffa and Hudaib, 2007) in which an item scores one if it appeared in the annual report, otherwise zero. To assess the sustainable performance of each bank based on the QBL, we used equally- and variance accounted for (VAF) loading-weighted indexes. The first index follows Haniffa and Hudaib (2007):

$$
E W Q B L_{j}=\frac{\sum_{t=1}^{n_{j}} X_{i j}}{n_{j}}
$$

where $E W Q B L_{j}$ is the equally weighted QBL index, $n_{j}$ is the number of items found in the annual report of the $j_{t h}$ bank, and $X_{i j}=1$ if the $i_{\text {th }}$ item is found, otherwise zero. The second approach is as follows:

$$
V A F L W Q B L j=\frac{\left(n_{c}\right) x\left(L_{w}\right) x\left(X_{i j}\right)}{100} \%
$$

where VAFLW $\mathrm{QBL}_{j}$ is the variance accounted for (VAF) loading-weighted QBL index, $n$ is the number of items, $n_{c}$ is the percentage item per component, $L_{w}$ is the proportion of the percentage loading factor, and $X_{i j}=1$ if the $i_{\text {th }}$ item is found in the annual report; otherwise, it is zero. To rank the level of sustainability for each bank, we used a reactive, defensive, accommodative, and proactive (RDAP) scale, recently modified by Hamidi and Worthington (2018).

\section{Results and discussion}

\section{Executing CATPCA}

We employed SPSS Version 24 to perform the CATPCA. Using the responses to the 31 items in the appendix and a cut-off of 0.55 for the loading score, we excluded seven items 
from the analysis. Each of the five dimensions has an eigenvalue greater than one, indicating that each component is appropriate for forming a separate factor. Table II provides details of the component loadings using varimax rotated scale items.

\section{$<$ INSERT TABLE II HERE $>$}

The next step was to check the reliability and validity of these components. Table III provides the results of various tests and interpretation of these results in which an additional 11 items were dropped to meet reliability and validity constraints. CATPCA then extracted the 13 remaining items and assigned them to four components (Table IV). The result shows better performance as the total percentage of variance accounted for improves from $64.61 \%$ to $72.89 \%$, indicating better communality (Table V). This means that the four selected components (1:37.15\%, 2: 14.99\%, 3: 12.66\%, 4: 8.09\%) describe almost $73 \%$ of the variance across the 13 items. According to Hinkin et al. (1997), while there are no specific rules for retaining items in a construct, four or six items per scale are appropriate if only half of the original items are in the final scale. Our final model indicates that all the constructs (dimension) have eigenvalues greater than one (Table V), further supported by a scree plot (not shown).

\section{$<$ INSERT TABLE III HERE $>$ \\ $<$ INSERT TABLE IV HERE $>$ \\ $<$ INSERT TABLE V HERE $>$}

Returning to the 13 items across the four dimensions in Table IV, we recognize these as follows. The construction of the first component is from items under environment, so we refer to this as 'planet'. The second component draws from two pillars of maqasid al-shari'ah: intellect ( 'aql) and posterity (nasl). Therefore, we refer to this as 'people'. The third component results from three items of faith ( $\mathrm{din}$ ), and so we include it as 'prophet'. The last component is a mix of another pillar of maqasid al-shari'ah and wealth ( $\mathrm{mal}$ ), so we refer to it as 'prosperity'. The only pillar of maqasid al-shari'ah that is not represented in the items and the resulting components is 'self' (nafs). All its items have loading factors less than 0.55 and fail to pass the necessary reliability and validity tests. 


\section{Results of content analysis}

We now assess the QBL performance of the 10 Islamic banks using these 13 items and content analysis of their annual reports over the three-year sample period. Figure 2 plots their scores using both an equally weighted index (the four Ps weighted equally in the total score) and the VAF loading-weighted index (the four Ps weighted according to their VAF share in Table V, which runs planet, people, prophet, and prosperity). Starting with the equally weighted index, BMI is the best performer with a score of $69.23 \%$, followed by MB with $66.75 \%$ and BMMB with $64.07 \%$. As all these scores were $>60 \%$, we rated them as proactive (doing more than is required) in meeting the 4Ps. The next two banks, ARB and JB, had close scores of $51.31 \%$ and $51.23 \%$, respectively, but as these were $>50 \%$ but $<60 \%$, we rated them as accommodative (doing all that is required). Clearly, some banks performed remarkably well in terms of the 4Ps, and certainly at least or much better than expected.

\section{$<$ INSERT FIGURE 2 HERE $>$}

In contrast, the next two banks, QIB (48.76\%) and KTKB (41.07\%), had 4P scores $>40 \%$ but $<50 \%$, for which we rated them as reactive (doing the least that is required). Finally, the remaining three banks, BB (35.85\%), AIB (30.77\%), and EI (7.69\%), had scores $<40 \%$. Therefore, we rated them as reactive (doing less than is required). Overall, if we compare the equally-weighted and VAF loading-weighted scores, which are relatively consistent, we find that half of the observed banks were either accommodative or proactive regarding the 4Ps and the other half were either defensive or reactive. Of course, the scoring is absolute, not relative, and while we ranked the banks according to their scores, there is no technical requirement for them to be distributed in any particular way.

\section{Sustainability performance}

Decomposing the scores further into the four dimensions, we found that our ten Islamic banks performed poorly in the 'planet' dimension (38\%), as illustrated in Figure 3. We expected this in that our stakeholders identified 'planet' as the leading concern, and it may be difficult for banks to meet this high standard. This is especially so because existing research finds that Islamic banks tend to largely ignore environmental matters (Mallin et al., 2014; Ali Aribi and Arun, 2015; Asutay and Harningtyas, 2015), thereby contradicting Islamic ethical teachings that encourage humans to preserve and harmoniously live with the environment 
(Abdelzaher et al., 2018; Helfaya et al., 2019). Possible ways of addressing this are highlighted in Figure 4, which include banks undertaking an environmental risk assessment, making the results known in their annual reports, and making greater efforts to promote green financing. However, a more mundane explanation for the latter may simply be that many Islamic banks follow Accounting and Auditing Organization for Islamic Financial Institution (AAOIFI) standards in which they are not required to disclose such information in their annual reports (Maali et al., 2006). This suggests the need to amend accounting and reporting standards for Islamic banks to meet the information needs of their stakeholders more fully.

\section{$<$ INSERT FIGURE 3 HERE $>$}

The other poorly performed area among the 4Ps for our Islamic banks was 'people' (41\%). As discussed, there is abundant theological support for the argument that Islamic banks should actively involve themselves in bettering society. Once again, as shown in Figure 4, Islamic banks seem to be good at providing social activities for their staff, library, and research facilities but do not seem to do much in rewarding creative work outside their organization or enhancing social solidarity. Islamic banks could move toward the latter by assisting groups having trouble in financing new business ventures such as the traditionally 'unbanked' (including the poor and women) and by developing financial literacy courses for their customers and stakeholders generally. Problematically, most CSR studies of Islamic banks find that social contribution is not a strong point of nearly all Islamic banks (Haniffa and Hudaib, 2007; Dusuki, 2008; Basah and Yusuf, 2013; Mallin et al., 2014; Alamer et al., 2015). This certainly needs much more thought in formulating a strategy.

'Prosperity' (53\%) is the second-best area in which Islamic banks performed better, with key areas for possible improvement, including employment opportunities and economic development. The first refers to what extent Islamic banks can open or create job opportunities. Other researchers highlight this as a commitment toward employees (Haniffa and Hudaib, 2007; Platonova et al., 2018). The second largely measures how Islamic banks can improve the access of customers to financial services and networks in rural areas. One possibility, albeit expensive, is the provision of a new banking infrastructure in remote areas. Fortunately, promising developments in Fintech and online banking suggest that it may be possible for Islamic banks to achieve this relatively cheaply were telecommunications services more broadly improved. 
As expected, the best performing dimension in our QBL was 'prophet' (63\%). Most of the banks appeared to make great efforts to report good governance, including the work of their Syari'ah boards in ensuring their products and services operate within Islamic law (77\%). Most of the banks also emphasized alms-giving (zakat) (73\%), a finding consistent with Maali et al. (2006), and this goes far in improving perceptions of their social performance (Gardberg et al., 2019). However, only one-third of the banks in our sample conducted and reported activities concerning an enabling environment for righteousness, for instance, by conducting regular religious lectures, daily prayers before work, or encouraging other religious activities. We argue that the promotion of religious or spiritual activities, to some extent, will enhance the commitment of both staff and customers alike (Ashmos and Duchon, 2000). This is important because religiosity is the key factor influencing customer choice to deal with Islamic banks (Alam et al., 2012; Souiden and Rani, 2015).

\section{Conclusion}

The purpose of this paper was to extend the TBL to the QBL to enable its application to Islamic banks. By surveying Islamic bank stakeholders of all kinds in Indonesia, we obtained their perceptions of 31 items developed from Chapra's corollaries of maqasid al-shari'ah. Using CATPCA, we then refined these into 13 items across the three conventional 3Ps of 'prosperity,' 'people,' and 'planet' along with an additional $\mathrm{P}$ reflecting 'prophet' being an additional but essential factor for assessing the performance of Islamic banks. Using these, we developed a QBL index and assessed the performance of ten Islamic banks across each dimension separately and together using content analysis of their annual reports over three years. This provided each bank with a score and a rank for the 4Ps and allowed us to categorize each bank according to their sustainability stance, whether proactive, accommodative, defensive, or reactive.

Overall, we found that our sample of Islamic banks paid relatively less attention to 'planet' (38\%) and 'people' (41\%) and more to 'prosperity' (53\%) and 'prophet' (63\%). This is comforting at first in that Islamic banks do indeed appear to be meeting their core point of departure from conventional banking in terms of conducting their operations in accordance with Islamic beliefs. However, it is also concerning that Islamic banks perform relatively poorly with regard to 'planet' and 'people', dimensions that an equally strong case for their inclusion can be made for in Islamic teaching. We identified several areas where there was a 
lack of alignment between stakeholder expectations and Islamic bank performance and suggested activities and/or reporting that may serve to improve practice in these areas.

Of course, the analysis includes several limitations that we readily acknowledge. First, our pilot survey focused on improving the understanding of the questions in the questionnaire and did not attempt to refine the actual number of items. This resulted in a relatively large number of items we could have excluded from the main survey to be possibly replaced by items to elicit finer details elsewhere. However, we have provided statistical evidence that the share of items excluded was not beyond the bounds of conventional practice. Second, we conducted our survey of perceptions and expectations of Islamic banking only in Indonesia. While practical, this limits the generalizability of our QBL. However, as the items in the surveys were quite simple and easily understood. Given our discussions with practitioners and regulators, we believe that Muslims in other contexts would respond similarly. Nonetheless, it would be useful to administer similar questionnaires in other countries to confirm its robustness.

In terms of contribution, we provide an initial test application of a QBL framework to assess Islamic bank sustainability that draws upon both religious teachings and the expectations and perceptions of actual bank stakeholders. We have also demonstrated how we can use the overall scores and those from the individual 4Ps to identify areas for improvement. This is of particular use to practitioners in Islamic banking and banking regulators, which can support this through appropriate training, guidance, and incentives. This is especially important as many countries with Islamic banking systems are increasingly placing their banks at the heart of broader policies aimed at social and economic development and environmental responsibility.

\section{References}

Abdelzaher, D. M., Kotb, A. and Helfaya, A. (2019), "Eco-Islam: Beyond the principles of why and what, and into the principles of how", Journal of Business Ethics, Vol. 155, No. 3, pp. 623-643.

Al-Qahtani, M. b. A. (2015), Understanding Maqasid Al-Shari’Ah: A Contemporary Perspective, International Institute of Islamic Thought (IIIT), Jeddah.

Alam, S. S., Janor, H., Zanariah, C. and Ahsan, M. N. (2012), "Is religiosity an important factor in influencing the intention to undertake Islamic home financing in Klang Valley?", World Applied Sciences Journal, Vol. 19, No. 7, pp. 1030-1041.

Alamer, A. R. A., Salamon, H. B., Qureshi, M. I. and Rasli, A. M. (2015), "CSR's measuring corporate social responsibility practice in Islamic banking: A review”, International Journal of Economics and Financial Issues, Vol. 5, No. 1S, pp. 198-206.

Ali, A. Y. (1991), The Holy Quran: English Translation of the Meanings and Commentary, King Fahd Holy Qur'an Printing, Madinah.

Allet, M. (2012), "Measuring the environmental performance of microfinance: A new tool", Journal of Cost Management, Vol. 26, No. 2, pp. 6-17. 
Ali Aribi, Z. A. and Arun, T. (2015), “Corporate social responsibility and Islamic Financial Institutions (IFIs): Management perceptions from IFIs in Bahrain”, Journal of Business Ethics, Vol. 129, No. 4, pp. 785794.

Ariff, M. and Rosly, S. A. (2011), "Islamic banking in Malaysia: Unchartered waters", Asian Economic Policy Review, Vol. 6, No. 2, pp. 301-319.

Ashmos, D. P. and Duchon, D. (2000), "Spirituality at work: A conceptualization and measure", Journal of Management Inquiry, Vol. 9, No. 2, pp. 134-145.

Assaf, A. G., Josiassen, A. and Cvelbar, L. K. (2012), "Does triple bottom line reporting improve hotel performance?”, International Journal of Hospitality Management, Vol. 31, No. 2, pp. 596-600.

Asutay, M. and Harningtyas, A. F. (2015), "Developing maqasid al-Shari'ah index to evaluate social performance of Islamic banks: A conceptual and empirical attempt”, International Journal of Islamic Economics and Finance Studies, Vol. 1, No. 1, pp. 5-64.

Auda, J. (2008), Maqasid Al-Shari'Ah as Philosophy of Islamic Law: A Systems Approach, International Institute of Islamic Thought (IIIT), Jeddah.

De Bakker, F. G. A., Groenewegen, P. and Den Hond, F. (2005), “A Bibliometric Analysis of 30 Years of Research and Theory on Corporate Social Responsibility and Corporate Social Performance", Business and Society, Vol. 44, No. 3, 283-317.

Bansal, P. and DesJardine, M. R. (2014), "Business sustainability: It is about time”, Strategic Organization, Vol. 12, No. 1, pp. 70-78.

Basah, M. Y. A. and Yusuf, M. M. (2013), "Islamic bank and corporate social responsibility (CSR)", European Journal of Business and Management, Vol. 5, No. 11, pp. 194-209.

Bedoui, H. E. and Mansour, W. (2015), "Performance and maqasid al-Shari'ah's pentagon-shaped ethical measurement", Science and Engineering Ethics, Vol. 21, No. 3, pp. 555-576.

Chapra, M. U. (2007a), "Challenges facing the Islamic financial industry", Hassan, M.K. and Lewis, M.K. (Eds.), Handbook of Islamic Banking, Edward Elgar, Cheltenham, pp. 325-357.

Chapra, M. U. (2007b), The Islamic Vision of Development in the Light of Maqasid Al-Shari'Ah, Islamic Research and Training Institute (IIIT), Jeddah.

Colbert, B. A. and Kurucz, E. C. (2007), "Three conceptions of triple bottom line business sustainability and the role for HRM", Human Resource Planning, Vol. 30, No. 1, pp. 21-30.

Comim, F. and Amaral, P. V. (2013), "The Human values index: Conceptual foundations and evidence from Brazil", Cambridge Journal of Economics, Vol. 37, No. 6, pp. 1221-1241.

Cornée, S. and Szafarz, A. (2014), "Vive la différence: Social banks and reciprocity in the credit market", Journal of Business Ethics, Vol. 125, No. 3, pp. 361-380.

Dusuki, A. W. (2008), "What does Islam say about corporate social responsibility", Review of Islamic Economics, Vol. 12, No. 1, pp. 5-28.

Dusuki, A. W. and Abdullah, N. I. (2007), "Maqasid al-Shari'ah, maslahah and corporate social responsibility", The American Journal of Islamic Social Sciences (AJISS), Vol. 24, No. 1, pp. 25-45.

Dyllick, T. and Hockerts, K. (2002), "Beyond the business case for corporate sustainability", Business Strategy and the Environment, Vol. 11, No. 2, pp. 130-141.

Elkington, J. (1997), Cannibals with Forks: The Triple Bottom Line of Twentieth Century Business, Capstone, Oxford.

Frederick, W. C. (1960), "The growing concern over business responsibility”, California Management Review, Vol. 2, No. 4, pp. 54-61.

Friedman, M. (1970), "The social responsibility of business is to increase its profits", New York Times Magazine, 13 September, pp. 32-33.

Gao, J. and Bansal, P. (2013), "Instrumental and integrative logics in business sustainability", Journal of Business Ethics, Vol. 112, No. 2, pp. 241-255.

Gardberg, N. A., Zyglidopoulos, S. C., Symeou, P. C. and Schepers, D. H. (2019), "The impact of corporate philanthropy on reputation for corporate social performance”, Business and Society, Vol. 58, No. 6, pp. 1177-1208.

Global Finance (2018), "World's best Islamic Financial Institution Awards 2018: Table of winners”, available at: $\quad$ https://www.gfmag.com/magazine/may-2018/worlds-best-islamic-financial-institutions-2018global-regional-and-country-winner-profiles (Accessed 15 August 2019). 
Hamidi, M. L. and Worthington, A. C. (2018), "Islamic social banking: The way forward", Malaysian Journal of Economics, Vol. 52, No. 1, pp. 195-207.

Hammer, J. and Pivo, G. (2017), "The triple bottom line and sustainable economic development theory and practice", Economic Development Quarterly, Vol. 31, No. 1, pp. 25-36.

Haniffa, R. and Hudaib, M. (2007), "Exploring the ethical identity of Islamic banks via communication in annual reports", Journal of Business Ethics, Vol. 76, No. 1, pp. 97-116.

Härdle, W. K. and Hlávka, Z. (2015), Multivariate Statistics: Exercises and Solutions, Springer, Berlin.

Hart, S. L. and Milstein, M. B. (2003), "Creating sustainable value”, Academy of Management Perspectives, Vol. 17, No. 2, pp. 56-67.

Hasan, H., Ali, S. S. and Muhammad, M. (2018), "Towards a maqasid al-Shari'ah based development index", Journal of Islamic Business and Management, Vol. 8, No. 1, pp. 20-36.

Helfaya, A., Kotb, A. and Hanafi, R. (2018), "Qur'anic ethics for environmental responsibility: Implications for business practice”, Journal of Business Ethics, Vol. 150, No. 4, pp. 1105-1128.

Hinkin, T. R., Tracey, J. B. and Enz, C. A. (1997), "Scale construction: Developing reliable and valid measurement instruments", Journal of Hospitality and Tourism Research, Vol. 21, No. 1, pp. 100-120.

Hollos, D., Blome, C. and Foerstl, K. (2012), "Does sustainable supplier co-operation affect performance? Examining implications for the triple bottom line", International Journal of Production Research, Vol. 50, No. 11, pp. 2968-2986.

Howard, W. J., Rhemtulla, M. and Little, T. D. (2015), "Using principal components as auxiliary variables in missing data estimation", Multivariate Behavioral Research, Vol. 50, No. 3, pp. 285-299.

Hubbard, G. (2009), "Measuring organizational performance: Beyond the triple bottom line”, Business Strategy and the Environment, Vol. 18, No. 3, pp. 177-191.

Islam, M. M. (2004), “Towards a green earth: An Islamic perspective”, Asian Affairs, Vol. 26, No. 4, pp. 44-89.

Kolb, R. W. (2011), "Risk management and risk transfer: Distributive justice in finance", The Journal of Alternative Investments, Vol. 13, No. 4, pp. 90-98.

Kotler, P. (2011), "Reinventing marketing to manage the environmental imperative", Journal of Marketing, Vol. 75, No. 4, pp. 132-135.

Kucukvar, M. and Tatari, O. (2013), "Towards a triple bottom-line sustainability assessment of the US construction industry”, The International Journal of Life Cycle Assessment, Vol. 18, No. 5, pp. 958-972.

Kumar, M., Tat Kee, F. and Taap Manshor, A. (2009), "Determining the relative importance of critical factors in delivering service quality of banks: An application of dominance analysis in SERVQUAL model", Managing Service Quality: An International Journal, Vol. 19, No. 2, pp. 211-228.

Linting, M., Meulman, J. J., Groenen, P. J. and van der Koojj, A. J. (2007), "Nonlinear principal components analysis: Introduction and application", Psychological Methods, Vol. 12, No. 3, pp. 336-358.

Longoni, A. and Cagliano, R. (2018), "Sustainable innovativeness and the triple bottom line: The role of organizational time perspective”, Journal of Business Ethics, Vol. 151, No. 4, pp. 1097-1120.

Maali, B. M. and Atmeh, M. A. (2015), "Using social welfare concepts to guarantee Islamic banks' deposits", International Journal of Islamic and Middle Eastern Finance and Management, Vol. 8, No. 2, pp. 134149.

Maali, B., Casson, P. and Napier, C. (2006), "Social reporting by Islamic banks", Abacus, Vol. 42, No. 2, pp. 266289.

Mallin, C., Farag, H. and Ow-Yong, K. (2014), "Corporate social responsibility and financial performance in Islamic banks", Journal of Economic Behavior and Organization, Vol. 103, pp. S21-S38.

Maltz, E., Thompson, F. and Ringold, D. J. (2011), "Assessing and maximizing corporate social initiatives: A strategic view of corporate social responsibility”, Journal of Public Affairs, Vol. 11, No. 4, pp. 344-352.

Mansour, W., Ben Jedidia, K. and Majdoub, J. (2015), "How ethical is Islamic banking in the light of the objectives of Islamic law?”, Journal of Religious Ethics, Vol. 43, No. 1, pp. 51-77.

Milne, M. J., Ball, A. and Gray, R. (2008), "Wither ecology? The triple bottom line, the global reporting initiative, and the institutionalization of corporate sustainability reporting", Journal of Business Ethics, Vol. 118, No. 1, pp. 13-29.

Mohammad, M. O. and Shahwan, S. (2013), "The objective of Islamic economic and Islamic banking in light of maqasid al-Shariah: A critical review”, Middle East Journal of Scientific Research, Vol. 13, No. 13, pp. 75-84. 
Mohammed, M. O., Tarique, K. M. and Islam, R. (2015), "Measuring the performance of Islamic banks using maqasid-based model”, Intellectual Discourse, Vol. 23, pp. 401-424.

Mohd Nor, S., Abdul Rahim, R. and Che Senik, Z. (2016), "The potentials of internalising social banking among the Malaysian Islamic banks", Environment, Development and Sustainability, Vol. 18, No. 2, pp. 347372.

Naqvi, S. N. H. (2016), Perspectives on morality and human well-being: A contribution to Islamic economics, The Islamic Foundation, Nairobi.

Nienhaus, V. (2011), "Islamic finance ethics and Shari'ah law in the aftermath of the crisis: Concept and practice of Shari'ah compliant finance", Ethical Perspectives, Vol. 18, No. 4, pp. 591-623.

Norman, W. and MacDonald, C. (2004), "Getting to the bottom of "triple bottom line"”, Business Ethics Quarterly, Vol. 14, No. 2, pp. 243-262.

Peattie, K. and Charter, M. (2003), “Green marketing”, Baker, M.J. (Ed.), The Marketing Book, ButterworthHienemann, Oxford, pp. 726-755.

Pikkarainen, K., Pikkarainen, T., Karjaluoto, H. and Pahnila, S. (2006), "The measurement of end-user computing satisfaction of online banking services: Empirical evidence from Finland”, International Journal of Bank Marketing, Vol. 24, No. 3, pp. 158-172.

Pinkse, J. and Kolk, A. (2010), "Challenges and trade-offs in corporate innovation for climate change", Business Strategy and the Environment, Vol. 19, No. 4, pp. n/a-n/a.

Platonova, E., Asutay, M., Dixon, R. and Mohammad, S. (2018), "The impact of corporate social responsibility disclosure on financial performance: Evidence from the GCC Islamic banking sector", Journal of Business Ethics, Vol. 151, No. 2, pp. 451-471.

Poon, W. C. (2007), 'Users' adoption of e-banking services: The Malaysian perspective”, Journal of Business and Industrial Marketing, Vol. 23, No. 1, pp. 59-69.

San-Jose, L., Retolaza, J. L. and Gutierrez-Goiria, J. (2011), “Are ethical banks different? A comparative analysis using the radical affinity index", Journal of Business Ethics, Vol. 100, No. 1, pp. 151-173.

Saukani, N. and Ismail, N. A. (2019), "Identifying the components of social capital by Categorical principal component analysis (CATPCA)", Social Indicators Research, Vol. 141, No. 2, pp. 631-655.

Slaper, T. F. and Hall, T. J. (2011), “The triple bottom line: What is it and how does it work", Indiana Business Review, Vol. 86, No. 1, pp. 4-8.

Souiden, N. and Rani, M. (2015), "Consumer attitudes and purchase intentions toward Islamic banks: The influence of religiosity”, International Journal of Bank Marketing, Vol. 33, No. 2, pp. 143-161.

Tate, W. L. and Bals, L. (2018), "Achieving shared triple bottom line (TBL) value creation: Toward a social resource-based view (SRBV) of the firm”, Journal of Business Ethics, Vol. 152, No. 3, pp. 803-826.

Triodos Bank (2019), “Integrated annual report 2019”, available at: https://annual-report-triodos.com/2019/ourgroup/key-figures-and-statistics/key-figures.html (Accessed 15 May 2020).

Usmani, M. T. (2002), An Introduction to Islamic Finance, (1st ed.), Kluwer Law International, London.

Vilanova, M., Lozano, J. M. and Arenas, D. (2009), "Exploring the nature of the relationship between CSR and competitiveness", Journal of Business Ethics, Vol. 87, No. S1, pp. 57-69.

Williams, G. and Zinkin, J. (2010), "Islam and CSR: A study of the compatibility between the tenets of Islam and the UN Global Compact”, Journal of Business Ethics, Vol. 91, No. 4, pp. 519-533.

Wilson, J. P. (2015), "The triple bottom line: Undertaking an economic, social, and environmental retail sustainability strategy", International Journal of Retail and Distribution Management, Vol. 43, No. 4/5, pp. 432-447. 


\begin{tabular}{|c|c|c|c|c|c|c|c|}
\hline & Characteristic & $\mathrm{N}$ & $\%$ & & Characteristic & $\mathrm{N}$ & $\%$ \\
\hline \multirow{2}{*}{$\begin{array}{l}\stackrel{x}{0} \\
\text {. }\end{array}$} & Male & 302 & 59.9 & \multirow{7}{*}{ 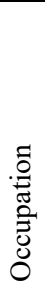 } & Manager/executive & 79 & 15.6 \\
\hline & Female & 202 & 40.1 & & Professional & 53 & 10.5 \\
\hline \multirow{5}{*}{$\stackrel{80}{\&}$} & $18-25$ years & 95 & 18.8 & & Academia & 42 & 8.3 \\
\hline & $26-35$ years & 201 & 39.9 & & Merchant/business owner & 40 & 7.9 \\
\hline & $36-45$ years & 127 & 25.2 & & Government employee & 37 & 7.5 \\
\hline & $46-55$ years & 68 & 13.5 & & Farmer & 2 & 0.4 \\
\hline & $>55$ years & 13 & 2.6 & & Housewife & 14 & 2.8 \\
\hline \multirow{7}{*}{ 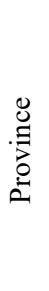 } & DKI & 96 & 19.0 & & Student & 30 & 6.1 \\
\hline & West Java & 173 & 34.3 & \multirow{6}{*}{ 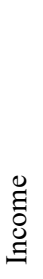 } & Unemployed & 1 & 0.2 \\
\hline & Banten & 23 & 4.6 & & Other & 206 & 40.9 \\
\hline & Central Java & 62 & 12.3 & & $<$ IDR $2,000,000$ & 66 & 13.1 \\
\hline & DIY & 86 & 17.1 & & IDR $2,000,000-5,000,000$ & 207 & 41.1 \\
\hline & East Java & 21 & 4.2 & & IDR $5,000,001-10,000,000$ & 110 & 21.8 \\
\hline & Outside Java & 43 & 8.5 & & IDR $10,000,001-20,000,000$ & 65 & 12.9 \\
\hline \multirow{4}{*}{$\frac{\tilde{0}}{.00}$} & Islam & 499 & 99.0 & \multirow{9}{*}{$\frac{0}{2}$} & $>$ IDR $20,000,000$ & 56 & 11.1 \\
\hline & Catholic & 3 & 0.6 & & Depositor only & 185 & 36.7 \\
\hline & Other Christian & 2 & 0.4 & & Depositor \& borrower & 88 & 17.5 \\
\hline & Primary/secondary School & 47 & 9.3 & & Depositor \& practitioner & 160 & 31.7 \\
\hline \multirow{5}{*}{ 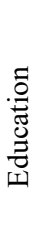 } & College diploma & 44 & 8.7 & & Depositor \& Syariah adviser & 3 & 0.6 \\
\hline & Bachelor degree & 297 & 58.9 & & Depositor \& regulator & 9 & 1.8 \\
\hline & Master degree & 96 & 19.0 & & Depositor \& academia & 15 & 3.0 \\
\hline & Doctoral degree & 16 & 3.2 & & Depositor \& stockholder & 2 & 0.4 \\
\hline & Other & 4 & 0.8 & & Community/other & 42 & 8.3 \\
\hline
\end{tabular}

Table I.

Respondent profile

\begin{tabular}{lccrrr}
\hline \multirow{2}{*}{ Item } & \multicolumn{5}{c}{ Dimension } \\
& 1 & \multicolumn{1}{c}{3} & \multicolumn{1}{c}{ 政 } & \multicolumn{1}{c}{5} \\
\hline SE4 & 0.188 & 0.159 & 0.433 & $\mathbf{0 . 5 1 5}$ & 0.023 \\
WE7 & 0.204 & 0.062 & 0.152 & $\mathbf{0 . 7 5 8}$ & 0.12 \\
WE8 & 0.318 & 0.119 & 0.170 & $\mathbf{0 . 7 8 0}$ & 0.006 \\
WE9 & 0.459 & 0.208 & -0.167 & 0.434 & 0.45 \\
WE10 & $\mathbf{0 . 5 7 2}$ & 0.200 & -0.020 & 0.295 & 0.323 \\
WE11 & $\mathbf{0 . 5 5 1}$ & 0.215 & 0.078 & 0.511 & 0.145 \\
IN12 & $\mathbf{0 . 5 8 3}$ & 0.162 & 0.271 & 0.380 & -0.031 \\
IN13 & $\mathbf{0 . 6 1 0}$ & 0.197 & 0.299 & 0.362 & -0.105 \\
IN14 & $\mathbf{0 . 8 0 4}$ & 0.096 & 0.167 & 0.153 & 0.025 \\
IN15 & $\mathbf{0 . 7 7 2}$ & 0.102 & 0.003 & 0.077 & 0.207 \\
PO16 & $\mathbf{0 . 7 8 3}$ & 0.122 & -0.049 & 0.020 & 0.283 \\
PO17 & $\mathbf{0 . 6 7 0}$ & 0.049 & 0.275 & 0.209 & -0.091 \\
PO18 & $\mathbf{0 . 6 2 4}$ & 0.088 & 0.328 & 0.235 & -0.148 \\
PO19 & $\mathbf{0 . 7 3 6}$ & 0.182 & 0.033 & 0.116 & 0.276 \\
EN20 & 0.159 & $\mathbf{0 . 6 6 7}$ & 0.270 & 0.230 & -0.037 \\
EN21 & 0.110 & $\mathbf{0 . 8 1 5}$ & 0.071 & 0.113 & 0.014 \\
EN22 & 0.130 & $\mathbf{0 . 8 1 5}$ & 0.049 & 0.017 & 0.233 \\
EN23 & 0.173 & $\mathbf{0 . 8 3 3}$ & 0.121 & 0.060 & 0.177 \\
EN24 & 0.138 & $\mathbf{0 . 7 5 3}$ & 0.091 & 0.084 & 0.219 \\
PR26 & 0.096 & 0.098 & $\mathbf{0 . 7 7 3}$ & 0.098 & 0.158 \\
PR27 & 0.174 & 0.097 & $\mathbf{0 . 7 6 1}$ & 0.140 & 0.197 \\
PR28 & 0.014 & 0.163 & 0.469 & 0.155 & $\mathbf{0 . 5 3 6}$ \\
PR29 & 0.076 & 0.205 & 0.301 & 0.079 & $\mathbf{0 . 6 9 2}$ \\
PR30 & 0.264 & 0.201 & 0.264 & -0.043 & $\mathbf{0 . 6 9 1}$ \\
PR31 & 0.116 & 0.159 & $\mathbf{0 . 7 2 7}$ & 0.120 & 0.164 \\
\hline
\end{tabular}

Table II.

CATPCA analysis 


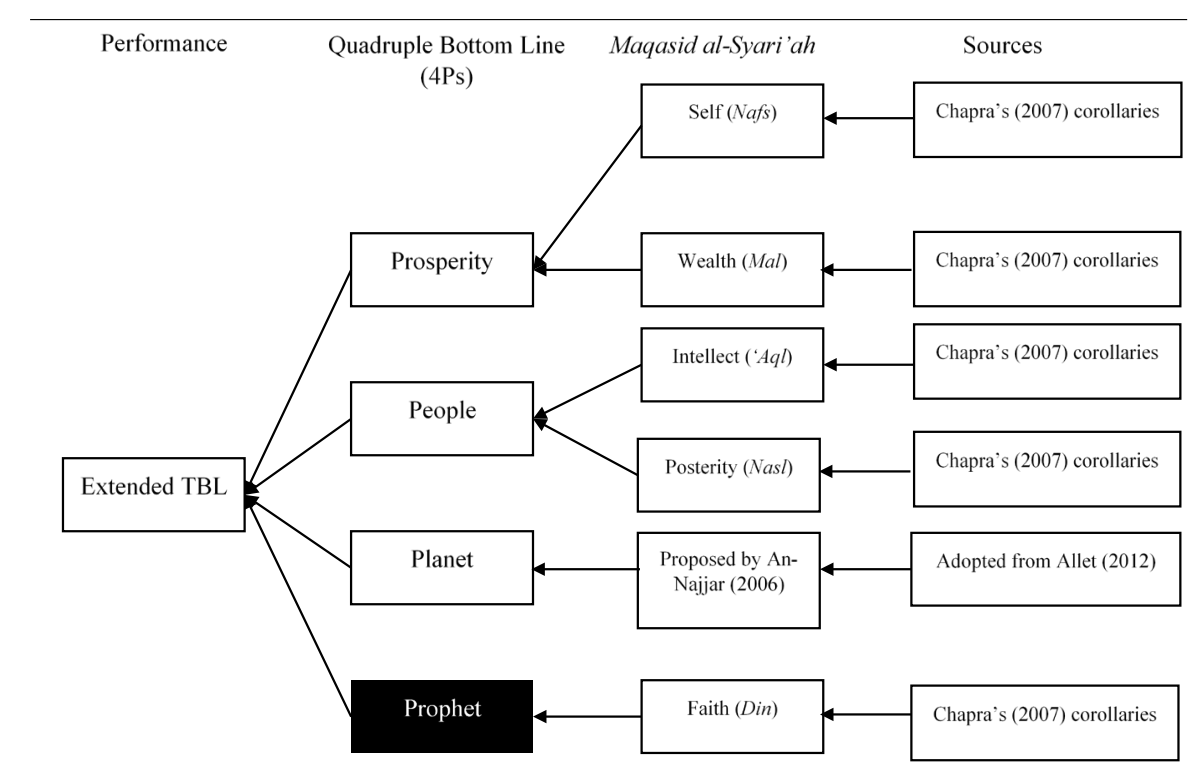

Figure 1. Extended TBL based on Maqasid al-Syari'ah principles

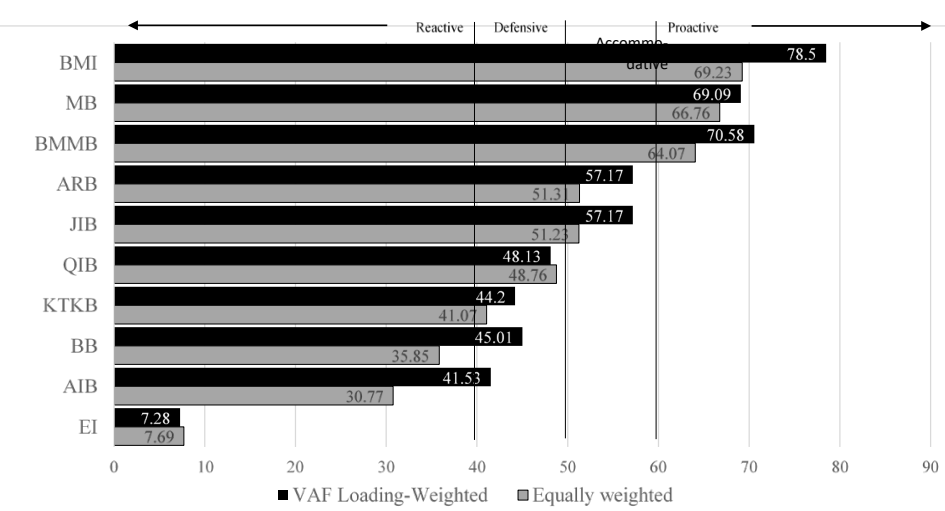

Figure 2.

QBL performance of selected Islamic banks 


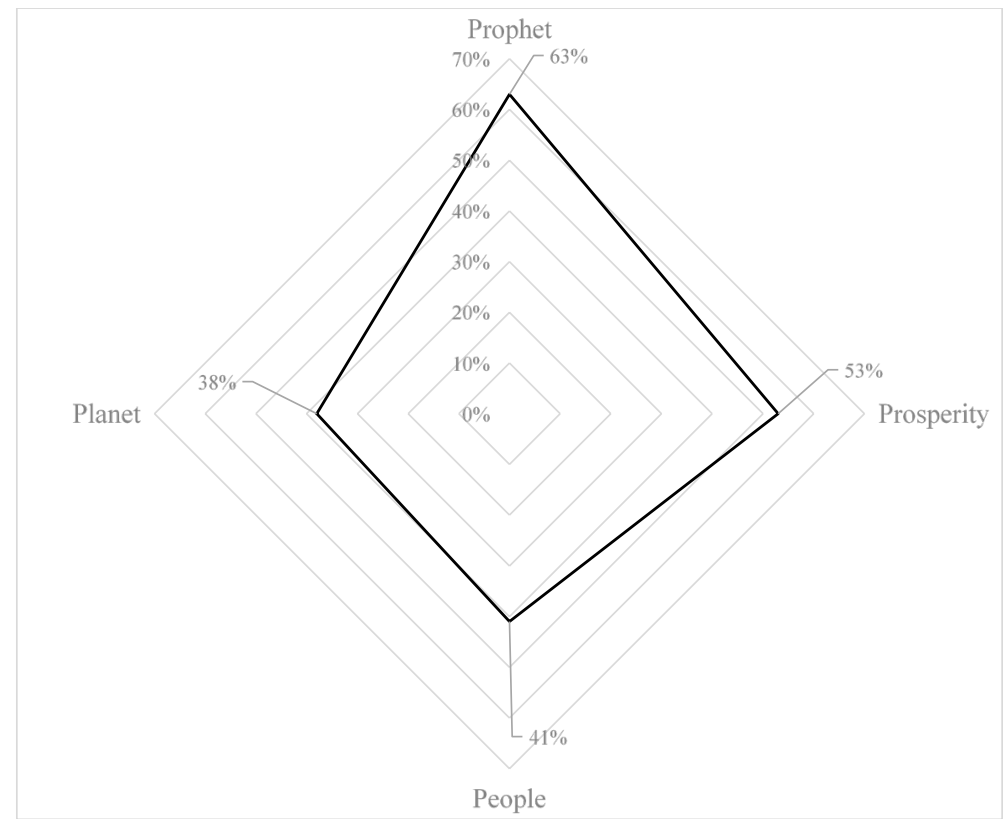

Figure 3.

QBL for all selected Islamic banks

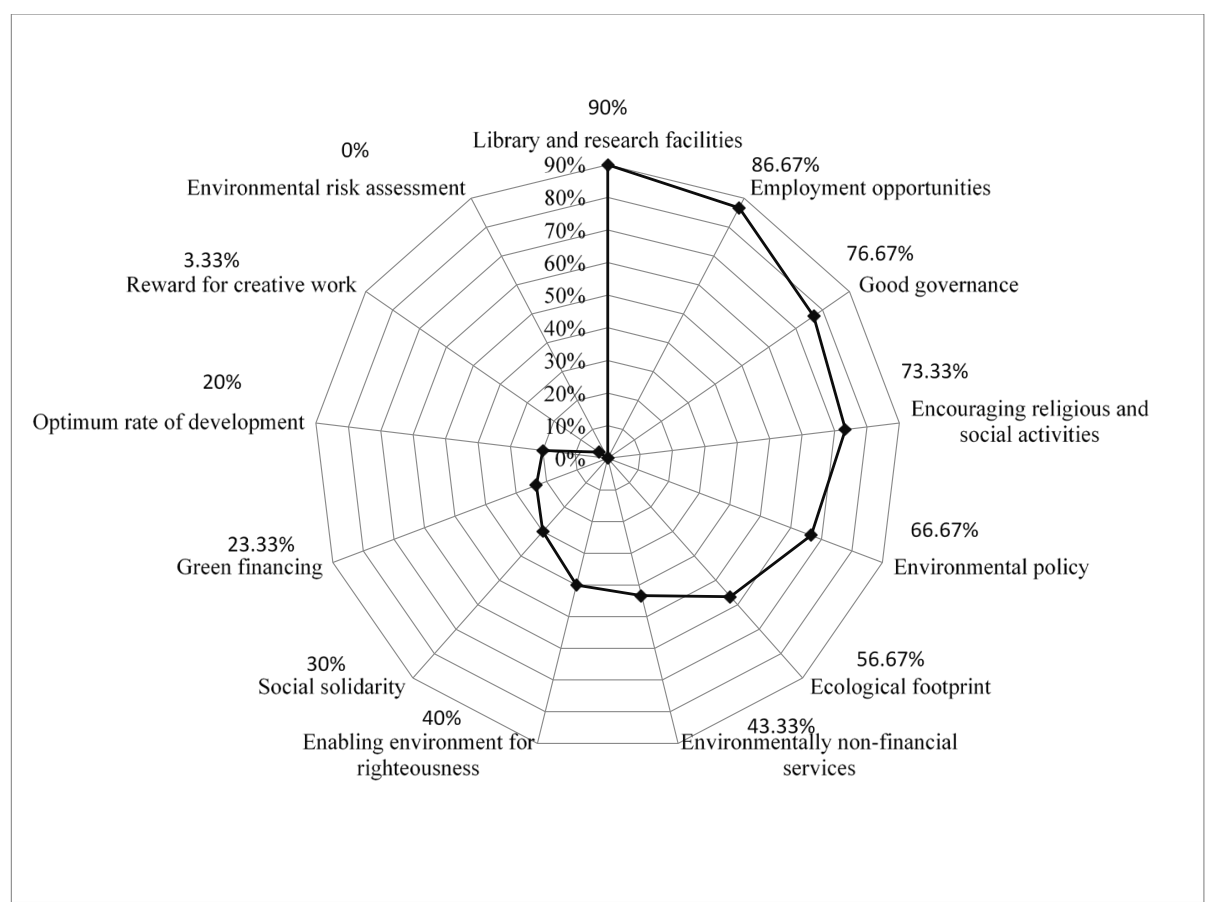

Figure 4.

QBL performance of Islamic banks by item 
QBL dimensions and items

\begin{tabular}{|c|c|c|c|}
\hline Dimension & Code & Corollaries & Items (Constructs) \\
\hline \multirow{11}{*}{ 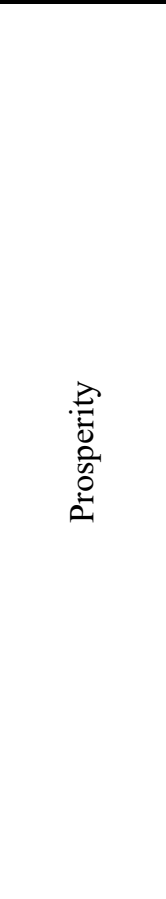 } & SE1 & Justice (fair dealing) & Islamic banks offer viable and competitive returns; \\
\hline & SE2 & $\begin{array}{l}\text { Equitable distribution of } \\
\text { Income and wealth }\end{array}$ & $\begin{array}{l}\text { Islamic banks currently collect and distribute alms } \\
\text { (zakat) from their employees; }\end{array}$ \\
\hline & SE3 & $\begin{array}{l}\text { Dignity, self-respect and social } \\
\text { equality }\end{array}$ & $\begin{array}{l}\text { Islamic banks offer equal working opportunity (i.e. } \\
\text { men and women are treated similarly); }\end{array}$ \\
\hline & SE4 & Good governance & $\begin{array}{l}\text { Islamic banks provide written statements on each of } \\
\text { their financing transactions; }\end{array}$ \\
\hline & SE5 & Mental peace and happiness & $\begin{array}{l}\text { Dealing with Islamic banks is less stressfull than } \\
\text { traditional banks as they don't charge interest (riba). }\end{array}$ \\
\hline & WE6 & $\begin{array}{l}\text { Security of life, property and } \\
\text { honour }\end{array}$ & $\begin{array}{l}\text { Deposits in Islamic banks are guaranteed by the } \\
\text { regulator; }\end{array}$ \\
\hline & WE7 & Optimum rate of development & Islamic banks' network currently reach rural areas; \\
\hline & WE8 & $\begin{array}{l}\text { Employment and self- } \\
\text { employment opportunities }\end{array}$ & Islamic banks open wider job opportunities; \\
\hline & WE9 & $\begin{array}{l}\text { Social solidarity and mutual } \\
\text { trust }\end{array}$ & $\begin{array}{l}\text { Islamic banks currently accept social collateral (i.e. } \\
\text { solidarity among groups or recommendation by a } \\
\text { trusted third party) to finance the poor; }\end{array}$ \\
\hline & WE10 & Saving and investment & $\begin{array}{l}\text { Islamic banks assist local community through financial } \\
\text { support (grants or interest free financing) for } \\
\text { community projects (school, hospital, places of } \\
\text { worship, etc); }\end{array}$ \\
\hline & WE11 & Removal of poverty & Islamic banks contribute to alleviating poverty. \\
\hline \multirow{8}{*}{$\frac{0}{2}$} & IN12 & $\begin{array}{l}\text { High quality of education at } \\
\text { affordable prices }\end{array}$ & $\begin{array}{l}\text { Islamic banks provide education and training for } \\
\text { employees and staff; }\end{array}$ \\
\hline & IN13 & $\begin{array}{l}\text { Expansion of knowledge and } \\
\text { technological base }\end{array}$ & $\begin{array}{l}\text { Islamic banks spread awareness of their products and } \\
\text { services to clients; }\end{array}$ \\
\hline & IN14 & Library and research facilities & $\begin{array}{l}\text { Islamic banks help to educate communities (i.e., } \\
\text { providing scholarship and other educational facilities); }\end{array}$ \\
\hline & IN15 & Reward for creative work & $\begin{array}{l}\text { Islamic banks should reward or give formal } \\
\text { appreciation for creative work. }\end{array}$ \\
\hline & PO16 & Need fulfilment & $\begin{array}{l}\text { Islamic banks provide financing to otherwise excluded } \\
\text { minority groups (i.e. women, illiterate individuals, } \\
\text { workers with insecure status); }\end{array}$ \\
\hline & PO17 & Clean and healthy environment & Islamic banks subsidise employees' health costs; \\
\hline & PO18 & $\begin{array}{l}\text { Freedom from debt servicing } \\
\text { burden }\end{array}$ & $\begin{array}{l}\text { Islamic banks's offer hardship options (such as } \\
\text { rescheduling of the financing) in case of clients' } \\
\text { financial difficulties; }\end{array}$ \\
\hline & PO19 & $\begin{array}{l}\text { Freedom from fear, conflict, } \\
\text { and security }\end{array}$ & $\begin{array}{l}\text { Islamic banks provide affordable financial services to } \\
\text { help deprived areas (such as areas affected by disasters } \\
\text { such as floods, volcanoes, earthquakes and conflict). }\end{array}$ \\
\hline \multirow{6}{*}{$\frac{\overleftrightarrow{ \pm}}{\stackrel{\Xi}{E}}$} & EN20 & Environmental policy & $\begin{array}{l}\text { Islamic banks should have a formal policy on } \\
\text { environmental responsibility; }\end{array}$ \\
\hline & EN21 & Ecological footprint & $\begin{array}{l}\text { Islamic banks should actively involve themselves in } \\
\text { reducing their ecological footprint (e.g. reduction in } \\
\text { energy consumption, water, waste, etc.); }\end{array}$ \\
\hline & EN22 & Green financing & $\begin{array}{l}\text { Islamic bank should provide a provision of financing } \\
\text { to promote the development of environment-friendly } \\
\text { activities; }\end{array}$ \\
\hline & EN23 & $\begin{array}{l}\text { Environmental nonfinancial } \\
\text { services }\end{array}$ & $\begin{array}{l}\text { Islamic banks should raise client's awareness of } \\
\text { environmental risks; }\end{array}$ \\
\hline & EN24 & Environmental risk assessment & $\begin{array}{l}\text { Islamic banks should use specific toolkits to evaluate } \\
\text { the environmental risks of clients' activities; }\end{array}$ \\
\hline & EN25 & Green financing & $\begin{array}{l}\text { Islamic banks should finance companies that do not } \\
\text { harm the environment. }\end{array}$ \\
\hline
\end{tabular}




\begin{tabular}{|c|c|c|c|}
\hline \multirow{6}{*}{ 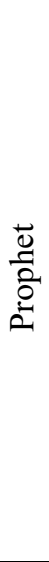 } & PR26 & $\begin{array}{l}\text { Enabling environment for } \\
\text { righteousness }\end{array}$ & $\begin{array}{l}\text { Islamic banks provide proper place for the employees } \\
\text { and clients to worship (praying) and encourage } \\
\text { religion activities; }\end{array}$ \\
\hline & PR27 & Family and social solidarity & $\begin{array}{l}\text { Islamic banks encouragesreligious and social activities } \\
\text { (such as Quranic recitation, Religious studies [taklim], } \\
\text { Dhuha prayer, distributing alms etc.); }\end{array}$ \\
\hline & PR28 & Values (profit-seeking) & $\begin{array}{l}\text { The motivation of dealing with Islamic bank is seeking } \\
\text { barakah rather than profit; }\end{array}$ \\
\hline & PR29 & Values (unlawful) & $\begin{array}{l}\text { Islamic banks declare unlawful (haram) transactions in } \\
\text { its financial report; }\end{array}$ \\
\hline & PR30 & Social solidarity & $\begin{array}{l}\text { Islamic banks provide free interest loan (qard al- } \\
\text { hasan) for the poor and disadvantaged groups; }\end{array}$ \\
\hline & PR31 & Good governance & $\begin{array}{l}\text { Islamic banks' products and services are under the } \\
\text { supervision of the Shari'ah Supervisory Board. }\end{array}$ \\
\hline
\end{tabular}

